\title{
Pre-hospital attitudes adopted by patients faced with the symptoms of acute myocardial infarction ${ }^{1}$
}

\author{
Viviane de Araújo Gouveia² \\ Edgar Guimarães Victor ${ }^{3}$ \\ Sandro Gonçalves de Lima ${ }^{4}$
}

This case series aimed to evaluate the behavior adopted by patients during the pre-hospital phase of acute myocardial infarction (AMI). A total of 115 AMI sufferers with ST-segment elevation were evaluated. The chi-square and Fisher's exact tests were applied. The individuals that did not associate the symptoms with cardiovascular disease most often attributed them to the following sources: gastrointestinal (38\%), musculoskeletal (29.7\%), food and/or medication poisoning (8.5\%) and arising from the respiratory apparatus (6.3\%). The proportion of major outcomes and of patients that arrived in the emergency department after 12 hours was higher among women, individuals with monthly income of up to one minimum wage, those who used analgesics and did not associate the symptoms with cardiovascular disease. It was found that individuals in unfavorable socioeconomic conditions, who interpreted the symptoms incorrectly, arrived later at the emergency department and had worse intra-hospital outcomes.

Descriptors: Myocardial Infarct; Symptoms; Health Knowledge, Attitudes, Practice.

\footnotetext{
${ }^{1}$ Article extracted from Master's Thesis "Atitudes pré-hospitalares de indivíduos atendidos em uma emergência cardiológica frente aos sintomas preditores de infarto agudo do miocárdio" presented to Universidade Federal de Pernambuco, PE, Brazil.

2 RN, M.Sc. in Health Sciences, Assistant Professor, Centro Acadêmico de Vitória, Universidade Federal de Pernambuco, PE, Brazil. E-mail: vivi_gouveia@yahoo.com.br.

${ }^{3}$ Physician, Ph.D. in Medicine, Full Professor, Universidade Federal de Pernambuco, PE, Brazil. E-mail: egvictor@oi.com.br.

4 Physician, Ph.D. in Health Public. Unidade de Terapia Intensiva, Hospital das Clínicas de Pernambuco, Universidade Federal de Pernambuco, PE, Brazil. E-mail: sandrolima@cardiol.br.
}

Corresponding Author:

Viviane de Araújo Gouveia

Rua São Paulo, 36

Bairro: Massaranduba, Prazeres

CEP: 54310-130, Jaboatão dos Guararapes, PE, Brasil

E-mail:vivi_gouveia@yahoo.com.br 


\title{
Atitudes pré-hospitalares adotadas por pacientes frente aos sintomas de infarto agudo do miocárdio
}

Esta série de casos teve o objetivo de avaliar as condutas adotadas pelos pacientes, durante a fase pré-hospitalar do infarto agudo do miocárdio (IAM). Avaliaram-se 115 indivíduos portadores de IAM, com supradesnivelamento do segmento ST. Foi aplicado o teste qui-quadrado e o teste exato de Fisher. Os indivíduos que não associaram os sintomas à doença cardiovascular atribuíram, mais frequentemente, às seguintes origens: gastrointestinal (38\%), osteomuscular (29,7\%), intoxicação alimentar e/ou medicamentosa $(8,5 \%)$ e decorrentes do aparelho respiratório $(6,3 \%)$. A proporção de desfechos maiores e de pacientes que chegaram à emergência após 12 horas foi mais elevada entre mulheres, indivíduos com renda mensal de até um salário mínimo, que usaram analgésicos e não associaram os sintomas à doença cardiovascular. Constatouse que indivíduos em condições socio-conômicas desfavoráveis, que interpretaram os sintomas de forma incorreta, chegaram mais tardiamente à emergência e apresentaram piores desfechos intra-hospitalares.

Descritores: Infarto do Miocárdio; Sintomas; Conhecimentos, Atitudes e Prática em Saúde.

\section{Actitudes prehospitalarias adoptadas por pacientes frente a los síntomas de infarto agudo del miocardio}

\begin{abstract}
Esta serie de casos tuvo el objetivo de evaluar las conductas adoptadas por los pacientes durante la fase prehospitalaria del infarto agudo del miocardio (IAM). Se evaluaron 115 individuos portadores de IAM con el segmento ST supradesnivelado. Fue aplicada la prueba Chi-cuadrado y la prueba exacta de Fisher. Los individuos que no asociaron los síntomas a la enfermedad cardiovascular la atribuyeron más frecuentemente a los siguientes orígenes: gastrointestinal (38\%), osteomuscular $(29,7 \%)$, intoxicación alimentar y/o medicamentosa $(8,5 \%)$ y provenientes del aparato respiratorio $(6,3 \%)$. La proporción de resultados más graves y de pacientes que llegaron a la emergencia después de 12 horas fue más elevada entre mujeres, individuos con renta mensual de hasta un salario mínimo, que usaron analgésicos y no asociaron los síntomas a la enfermedad cardiovascular. Se constató que individuos en condiciones socioeconómicas desfavorables, que interpretaron los síntomas de forma incorrecta, llegaron más tarde a la emergencia y presentaron peores resultados intrahospitalarios.
\end{abstract}

Descriptores: Infarto del Miocardio; Síntomas; Conocimientos, Actitudes y Práctica en Salud.

\section{Introduction}

The pre-hospital phase in Acute Myocardial Infarction (AMI) care, is comprehended as the onset of pain and the recognition of the symptomology by the patient, up to seeking first aid, including travelling time to the nearest hospital service(1-2). According to data of the American Heart Association (AHA), transport to hospital is the phase where more time is lost. It is estimated that the time interval between the appearance of symptoms and the arrival at the emergency unit ranges from an hour and a half to six hours ${ }^{(2-3)}$. To guarantee a good prognosis, it is ideal that patients should not exceed more than 45 minutes between the interpretation of the symptoms and the search for healthcare. The presentation of AMI ranges from classic to nonspecific symptoms, which can interfere with the choice of appropriate behavior for the treatment ${ }^{(4)}$. The correct interpretation of the 
symptoms results in a decrease in the delay of arrival at the emergency unit. However, the lack of autonomy and the progressive disability caused by the onset and progression of the symptoms may contribute to the individual becoming more passive in relation to the situation, reducing the chances of survival(4-5).

The importance that the patient attributes to the symptoms also influences the choice of behavior (6-7). In a study conducted by the AHA, it was observed that the majority of the patients did not attribute great importance to the symptoms of AMI, classifying them as "irrelevant" and the behavior related to this interpretation was to wait for the symptoms to finish ${ }^{(8)}$. Some socio-cultural characteristics, such as religion, gender, education level and number of people per domicile, may also influence the choice of behavior(9-10). The aim of this study was to evaluate the pre-hospital attitudes faced with the symptoms suggestive of AMI in patients attended in a cardiology emergency unit.

\section{Method}

This is a descriptive case series study, conducted from February to June 2008, in the Cardiology Emergency Unit of Pernambuco/PROCAPE. The sample consisted of hospitalized individuals with a confirmed diagnosis of AMI with ST segment elevation. Individuals were excluded who were not able to provide information because they were suffering from mental disorders or were undergoing pharmacological treatment that interfered with cognition, or even due to unfavorable clinical conditions such as: cardiogenic shock, acute pulmonary edema, respiratory failure and mechanical ventilation, among others. The interpretations by the patients of the symptoms were classified as being of cardiovascular origin or originating in other systems. Behaviors defined as beneficial for the treatment of AMI were those recommended by the III Brazilian Guidelines for the Treatment of AMI ${ }^{(1)}$. Myocardial Revascularization Surgery (MRS), coronary angioplasty, angina recurrence during the period of hospitalization, cerebrovascular accident (CVA) and death were considered as major outcomes.

To collect the data a questionnaire was used which included questions regarding the socio-economic and demographic conditions, pre-hospital behavior performed by the individuals faced with predictor symptoms of AMI, past morbidity and cardiovascular risk factors. The outcomes were collected through the medical records. With the intention of minimizing memory bias, the maximum time for the application of the questionnaire was 48 hours after admission to the cardiology emergency unit. For the analysis of the variables the chi-square test or the Fisher's exact test were applied as necessary. All the conclusions were based on a significance level of $5 \%$. The software used was Excel 2000 and SPSS version 8.0. The research project was approved by the research ethics committee of the Health Sciences Center of the Federal University of Pernambuco (CCS/UFPE) under protocol number 405/07.

\section{Results}

The sample was composed of 115 individuals. The majority $(94.8 \%)$ of the interviewees lived in brick built houses, with a mean of 3.8 inhabitants per domicile, outside the municipality of Recife, and had a mean monthly income of 1.7 minimum wages (Table 1 ).

Table 1 - Distribution of the evaluated patients by sociodemographic characteristics. Recife, PE, Brazil, 2009

\begin{tabular}{lll}
\hline \multicolumn{1}{l}{ Socio-demographic characteristics } & $\mathbf{n}$ & $\%$ \\
\hline Gender & 79 & 68.7 \\
Male & 36 & 31.3 \\
Female & & \\
Age $(60.8 \pm 12.6)$ & 28 & 24.3 \\
Up to 60 & 87 & 75.7 \\
$>60$ & & \\
Schooling & 32 & 27.8 \\
Illiterate & 44 & 38.3 \\
Pre-school education & 22 & 19.1 \\
Elementary education & 10 & 8.7 \\
High school education & 7 & 6.1 \\
Higher education & & \\
Skin color & 41 & 35.7 \\
White & 74 & 64.3 \\
Non-white & & \\
\hline
\end{tabular}

The individuals that interpreted the symptoms as unrelated to cardiovascular disease, most often attributed them to the following sources: digestive system (38\%), musculoskeletal system (29.7\%), food and/or medication poisoning (8.5\%) and the respiratory apparatus (6.3\%). A small percentage (9.6\%) opted for two or more behaviors simultaneously or in sequence faced with the symptoms presented. Only $18.7 \%$ of the individuals chose, at least, one behavior that really resulted in benefit for their health condition. An expressive variety of behaviors were registered, such as: 
use of medications without cardiovascular effects and teas, bath, local massage, performing physical exercise, prayer, ingestion of water, induction of vomiting, topical application of alcohol, ingestion of alcoholic spirits, and measurement of arterial pressure.

About $90 \%$ of the sample had at least one risk factor for cardiovascular disease and $20 \%$ of the participants had at least one comorbidity. The duration from the onset of symptoms to the arrival at the emergency unit varied from 30 minutes to five days. This disparity justifies the mean travel time of 53 hours, although 61 patients (53\%) arrived within 12 hours. The analysis of the outcomes presented by the individuals up to the hospital discharge revealed that $3.5 \%$ of the interviewees presented more than one outcome. During a short period of time in which the institution had no thrombolytics, some of the 86 patients who received hospital discharge were transferred to other hospitals or discharged to perform the procedure(s) later (Table 2).

Table 2 - Distribution of the evaluated patients by clinical characteristics and behaviors adopted faced with the predictor symptoms of AMI. Recife, PE, Brazil, 2009

\begin{tabular}{lrr}
\multicolumn{1}{c}{ Clinical characteristics } & $\mathbf{n}$ & $\%$ \\
\hline Interpretation of the symptoms & & \\
Cardiovascular origin & 42 & 36.5 \\
Other origins & 47 & 40.9 \\
Did not have an opinion & 26 & 22.6 \\
Behavior & & \\
None & 52 & 45.2 \\
Rest & 17 & 14.8 \\
& & (continue...)
\end{tabular}

Table 2 - (continuation)

\begin{tabular}{|c|c|c|}
\hline Clinical characteristics & $\mathbf{n}$ & $\%$ \\
\hline Aspirin & 1 & 0.9 \\
\hline Analgesic & 12 & 10.4 \\
\hline Nitrate & 3 & 2.6 \\
\hline Others & 43 & 37.4 \\
\hline \multicolumn{3}{|l|}{ Behavior beneficial for the treatment of AMI } \\
\hline Yes & 20 & 36.4 \\
\hline No & 35 & 63.6 \\
\hline \multicolumn{3}{|l|}{ Risk Factors } \\
\hline Hypertension & 82 & 78.8 \\
\hline DM & 33 & 31.7 \\
\hline Smoker & 54 & 51.9 \\
\hline Dyslipidemia & 25 & 24.0 \\
\hline \multicolumn{3}{|l|}{ Comorbidities } \\
\hline CAD & 10 & 41.7 \\
\hline CVA & 5 & 20.8 \\
\hline Non-ischemic heart diseases & 5 & 20.8 \\
\hline Others & 6 & 25.0 \\
\hline \multicolumn{3}{|l|}{ Outcomes } \\
\hline Myocardial Revascularization Surgery (MRS) & 8 & 7.0 \\
\hline Angioplasty & 7 & 6.1 \\
\hline Recurrence of angina/AMI & 7 & 6.1 \\
\hline CVA & 2 & 1.7 \\
\hline Death & 11 & 9.6 \\
\hline Hospital discharge & 86 & 74.8 \\
\hline
\end{tabular}

Elapsed time from symptom onset to admission to the emergency unit

Up to $12 \mathrm{~h} \quad 61 \quad 53.0$

$\begin{array}{lll}>12 \mathrm{~h} & 54 & 47.0\end{array}$

AMI: Acute Myocardial Infarction; M: Diabetes Mellitus; CAD: Coronary Artery Disease; CVA: Cerebrovascular Accident.

Although not statistically significant, a higher proportion of women with low monthly incomes and without anyone present during the AMI presented more travel time to the emergency unit and a higher proportion and major outcomes (Table 3).

Table 3 - Distribution of the evaluated patients by socio-demographic and clinical characteristics according to elapsed time from symptom onset to admission to the emergency unit. Recife, PE, Brazil, 2009

\begin{tabular}{|c|c|c|c|c|c|}
\hline \multirow{3}{*}{ Socio-demographic and clinical characteristics } & \multicolumn{4}{|c|}{$\begin{array}{l}\text { Elapsed time from symptom onset to admission to the } \\
\text { emergency unit }\end{array}$} & \multirow{3}{*}{$p$-value } \\
\hline & \multicolumn{2}{|c|}{ Up to $12 \mathrm{~h}$} & \multicolumn{2}{|c|}{$>12 h$} & \\
\hline & $\mathbf{n}$ & $\%$ & $\mathbf{n}$ & $\%$ & \\
\hline \multicolumn{6}{|l|}{ Gender } \\
\hline Male & 42 & 53.2 & 37 & 46.8 & \\
\hline Female & 19 & 52.8 & 17 & 47.2 & 1.000 \\
\hline \multicolumn{6}{|l|}{ Age } \\
\hline Up to 60 & 19 & 67.9 & 9 & 32.1 & \\
\hline$>60$ & 42 & 48.3 & 45 & 51.7 & 0.084 \\
\hline \multicolumn{6}{|l|}{ Skin color } \\
\hline White & 26 & 63.4 & 15 & 36.6 & \\
\hline Non-white & 35 & 47.3 & 39 & 52.7 & 0.120 \\
\hline
\end{tabular}


Table 3 - (continuation)

\begin{tabular}{|c|c|c|c|c|c|}
\hline \multirow{3}{*}{ Socio-demographic and clinical characteristics } & \multicolumn{4}{|c|}{$\begin{array}{l}\text { Elapsed time from symptom onset to admission to the } \\
\text { emergency unit }\end{array}$} & \multirow{3}{*}{ p-value } \\
\hline & \multicolumn{2}{|c|}{ Up to $12 \mathrm{~h}$} & \multicolumn{2}{|c|}{$>12 h$} & \\
\hline & $\mathbf{n}$ & $\%$ & $\mathbf{n}$ & $\%$ & \\
\hline Recife & 23 & 60.5 & 15 & 39.5 & \\
\hline Outside the city of Recife & 38 & 49.4 & 39 & 50.6 & 0.322 \\
\hline \multicolumn{6}{|l|}{ Monthly Income } \\
\hline Up to 1 M.W. & 30 & 46.9 & 34 & 53.1 & \\
\hline > 1 M.W. & 31 & 60.8 & 20 & 39.2 & 0.188 \\
\hline \multicolumn{6}{|l|}{ Others present during the AMI } \\
\hline Family members & 36 & 50.0 & 36 & 50.0 & \\
\hline Others & 16 & 69.6 & 7 & 30.4 & \\
\hline None & 9 & 45.0 & 11 & 55.0 & 0.191 \\
\hline \multicolumn{6}{|l|}{ Interpretation of the symptoms } \\
\hline Cardiovascular origin & 25 & 59.5 & 17 & 40.5 & \\
\hline Other origins & 25 & 53.2 & 22 & 46.8 & \\
\hline Did not have an opinion & 11 & 42.3 & 15 & 57.7 & 0.384 \\
\hline \multicolumn{6}{|l|}{ Behavior } \\
\hline None & 29 & 47.5 & 23 & 42.6 & 0.595 \\
\hline Rest & 9 & 14.8 & 8 & 14.8 & 0.992 \\
\hline Aspirin & 0 & 0.0 & 1 & 1.9 & 0.470 \\
\hline Analgesic & 3 & 4.9 & 9 & 16.7 & 0.040 \\
\hline Nitrate & 0 & 0.0 & 3 & 5.6 & 0.100 \\
\hline Others & 24 & 39.3 & 19 & 35.2 & 0.645 \\
\hline \multicolumn{6}{|l|}{ Behavior beneficial for the treatment of AMI } \\
\hline Yes & 8 & 40.0 & 12 & 60.0 & \\
\hline No & 22 & 62.9 & 13 & 37.1 & 0.101 \\
\hline
\end{tabular}

MW.: Minimum Wage; AMI: Acute Myocardial Infarction.

The proportion of individuals who arrived at the emergency department after more than 12 hours was significantly higher among those who self-medicated with analgesics $(p=0.040)$. A higher percentage of individuals who interpreted the symptoms as not arising from the heart and did not engage in any conduct when the symptoms presented arrived later at the emergency unit, presenting a higher proportion of major outcomes (Table 4).

Table 4 - Distribution of the evaluated patients by socio-demographic and clinical characteristics according to the major outcomes. Recife, PE, Brazil, 2009

\begin{tabular}{|c|c|c|c|c|c|}
\hline \multirow{3}{*}{ Socio-demographic and clinical characteristics } & \multicolumn{4}{|c|}{ Major outcomes } & \multirow{3}{*}{ p-value } \\
\hline & \multicolumn{2}{|c|}{ No } & \multicolumn{2}{|c|}{ Yes } & \\
\hline & $n$ & $\%$ & n & $\%$ & \\
\hline \multicolumn{6}{|l|}{ Gender } \\
\hline Male & 62 & 78.5 & 17 & 21.5 & \\
\hline Female & 24 & 66.7 & 12 & 33.3 & 0.176 \\
\hline \multicolumn{6}{|l|}{ Age Group } \\
\hline Up to 60 & 19 & 67.9 & 9 & 32.1 & \\
\hline$>60$ & 67 & 77.0 & 20 & 23.0 & 0.453 \\
\hline \multicolumn{6}{|l|}{ Skin color } \\
\hline White & 32 & 78.0 & 9 & 22.0 & \\
\hline Non-white & 54 & 73.0 & 20 & 27.0 & 0.548 \\
\hline \multicolumn{6}{|l|}{ Monthly Income } \\
\hline Up to $1 \mathrm{MW}$ & 45 & 70.3 & 19 & 29.7 & \\
\hline > 1 M.W. & 41 & 80.4 & 10 & 19.6 & $\begin{array}{c}0.216 \\
\text { (continue }\end{array}$ \\
\hline
\end{tabular}


Table 4 - (continuation)

\begin{tabular}{|c|c|c|c|c|c|}
\hline \multirow{3}{*}{ Socio-demographic and clinical characteristics } & \multicolumn{4}{|c|}{ Major outcomes } & \multirow{3}{*}{ p-value } \\
\hline & \multicolumn{2}{|c|}{ No } & \multicolumn{2}{|c|}{ Yes } & \\
\hline & $\mathbf{n}$ & $\%$ & n & $\%$ & \\
\hline \multicolumn{6}{|l|}{ Witnesses during the AMI } \\
\hline Family members & 58 & 80.6 & 14 & 19.4 & \\
\hline Others & 15 & 65.2 & 8 & 34.8 & \\
\hline None & 13 & 65.0 & 7 & 35.0 & 0.182 \\
\hline \multicolumn{6}{|l|}{ Interpretation of the symptoms } \\
\hline Cardiovascular origin & 32 & 76.2 & 10 & 23.8 & \\
\hline Other origins & 34 & 72.3 & 13 & 27.7 & \\
\hline Did not have an opinion & 20 & 76.9 & 6 & 23.1 & 0.880 \\
\hline \multicolumn{6}{|l|}{ Behavior } \\
\hline None & 42 & 48.8 & 10 & 34.5 & 0.179 \\
\hline Rest & 13 & 15.1 & 4 & 13.8 & 1.000 \\
\hline Aspirin & 0 & 0.0 & 1 & 3.4 & 0.252 \\
\hline Analgesic & 11 & 12.8 & 1 & 3.4 & 0.290 \\
\hline Nitrate & 2 & 2.3 & 1 & 3.4 & 1.000 \\
\hline Others & 28 & 32.6 & 15 & 51.7 & 0.065 \\
\hline \multicolumn{6}{|l|}{ Behavior beneficial for the treatment of AMI } \\
\hline Yes & 16 & 80.0 & 4 & 20.0 & \\
\hline No & 23 & 65.7 & 12 & 34.3 & 0.262 \\
\hline
\end{tabular}

MW.: Minimum Wage; AMI: Acute Myocardial Infarction.

\section{Discussion}

Socio-demographic and clinical factors are able to interfere with the interpretation and choice of behavior by the patients, thus influencing the time for seeking care and the start of thrombolysis and, therefore, the prognosis and survival of the individuals ${ }^{(2,9-10)}$. The low level of education and the limited financial conditions identified in this sample may have limited the access of these individuals to health education, influencing the time to search for health services of high complexity confirming the findings of other authors ${ }^{(10)}$. The majority of the people interpreted the symptoms as problems of gastrointestinal origin. These data are consistent with studies conducted in England and in Sweden where the majority of the patients interpreted the symptoms as indigestion or of musculoskeletal origin(11-12).

Although the majority arrived in the emergency unit within $12 \mathrm{~h}$, few adopted pre-hospital behavior that would result in benefit to the AMI condition. A qualitative study performed in England, with a sample of ten women, evaluated the perception of the symptoms of AMI. The results showed that there was consistency between the interpretation of the symptoms and the behavior adopted by the patients(12). Similar to the findings of the present study, another study showed that men and younger people took less time to seek health services when compared with women and the elderly, who had more difficulties to interpret the symptoms as being an
AMI episode and presented more atypical symptoms ${ }^{(13)}$. These data may in part account for the high female intra-hospital mortality after the first 24 hours of hospitalization for AMI and the delay in introducing thrombolysis(14-15).

Even without a statistically significant association, the majority of patients who arrived at the emergency unit within 12 hours were residents of the city of Recife, white, and had better financial conditions. These findings are similar to those of studies that evaluated the difference in the perception of the symptoms between black and white people and between people of different financial conditions ${ }^{(16)}$. A multicentric study showed that patients in Australia and New Zealand took less time to arrive at the emergency unit, when compared with Brazilians and Argentineans ${ }^{(17)}$. Among those individuals who arrived earlier at the emergency unit, a large percentage were accompanied by people unrelated to them. Conversely, authors who have studied the influence of the interpretation of the symptoms on the time taken to arrive at the hospital, verified that family members more often suggest attitudes that delayed the time of arrival at the emergency unit, when compared to people unrelated to the victim(18).

The majority of the patients who interpreted the symptoms as cardiovascular disease (CVD) managed to arrive at the emergency unit within 12 hours. These 
data are similar to the results of other studies where the majority of the individuals who interpreted the symptoms as being of another origin took more time to seek assistance ${ }^{(19)}$. In a multicenter study that evaluated 228 patients it was verified that only $25 \%$ of them recognized the symptoms as CVD and that the faster decisions were taken by those who interpreted the symptoms correctly(19). Another study carried out in Japan showed that the patients who associated the symptoms with CVD, sought the emergency services more quickly and arrived with more chance of undergoing mechanical thrombolysis(20).

The delay in seeking care can be influenced by the location of the AMI, age, duration of symptoms, negative experience with previous hospital treatment, fear, changes in pain perception, deficiency in the autonomy of self-healthcare, cultural factors/popular beliefs, difficulties in the access to education and health services due to unfavorable geographical location and/ or limited financial conditions, and low education level, among others ${ }^{(14,21)}$. The majority of the patients who used nitrates and aspirin arrived at the emergency unit after 12 hours. These behaviors may have contributed, in part, to the delay in the decision to go to the hospital. This hypothesis can be confirmed by a statistically significant association between the use of analgesics and the prolonged time to arrive at the emergency unit. Individuals that arrived at the emergency unit earlier adopted less appropriate measures to deal with the symptoms and, perhaps due to this, went more rapidly to the emergency unit, since the behaviors adopted did not produce a beneficial effect or may have even contributed to the worsening of clinical condition.

Among the patients who had major outcomes a higher proportion of females was observed, aged up to 60 years, with low levels of education, non-white skin color, with a monthly income of up to one minimum wage and with no one present during the episode. Some studies have shown that individuals with white skin color, with better financial conditions and more education were quicker in seeking clinical care in relation to nonwhite people ${ }^{(22)}$. This might be explained by the fact that individuals with unfavorable social conditions take longer to access emergency services, delaying the time to the start of thrombolysis. It is possible that the small sample size may have influenced the lack of statistically significant association, and that measurement bias in relation to the variable outcome occurred due to deficiencies of the service, which did not always offer all the procedures in the different levels of complexity. In addition, for a short period of time the institution had no thrombolytics. Thus, some patients were transferred to other hospitals or discharged to perform the procedure(s) later.

Popular education is one of the fundamental tools of health promotion. Knowledge about the symptoms of a disease can influence the interpretation of these and consequently the behavior adopted by the patient and, in the majority of cases, this will be consistent with the interpretation that the patient attributes to the symptoms. Therefore, it is necessary to guide the population through educational campaigns, rationally and backed by scientific data, and to disseminate the symptoms of AMI, especially among the elderly and women, as these groups presented greater delay in searching for healthcare. While performing health education activities, it is important that the professionals adopt strategies that can encourage and respect the notion of the patient as an individual responsible for their own health, this can start the process that leads to improvement, recognizing in themselves the need to change their attitude when faced with the predictive symptoms of the disease ${ }^{(23)}$. In this perspective, the health professionals are democratizing knowledge, respecting autonomy, and potentializing the self-care capacity in the patients, contributing to the reduction of mortality from AMI.

\section{Conclusion}

Individuals with unfavorable socioeconomic conditions, who interpreted the symptoms incorrectly and did not adopt any behavior when the symptoms presented, arrived later at the emergency unit and presented worse intra-hospital outcomes.

\section{References}

1. Sociedade Brasileira de Cardiologia. III Diretriz sobre Tratamento do Infarto Agudo do Miocárdio. Arq Bras Cardiol. 2004;83(supl 2):1-86.

2. Moser DK, Kimble LP, Alberts MJ, Alonzo A, Croft JB, Dracup $K$, et al. Reducing delay in seeking treatment by pacients with acute coronary syndrome and stroke. A scientific statement from the American Heart Association Council on Cardiovascular Nursing and stroke Council. Circulation. 2006;114(2):175-89.

3. Lovlien M, Schei B, Hole T. Prehospital delay, contributing aspects and responses to symptoms among Norwegian women and men with first time acute myocardial infarction. Eur J Cardiovasc Nurs. 2007;6(4):308-13. 
4. Ottesen MM, Dixen U, Torp-Pedersen C, Kober L. Prehospital delay in acute coronary syndrome - an analysis of the components of delay. Int J Cardiol. 2004;96(1):97-103.

5. Mensah GA, Hand MM, Antman EM, Ryan TJ Jr, Schriever R, Smith SC Jr. Development of system of care for st-elevation myocardial infartion patients: the patient and public perspective. Circulation. 2007;116(2):33-8.

6. Caldwell MA, Miaskowski C. Mass media interventions to reduce help-seeking delay in people with symptoms of acute myocardial infarction: time for a new approach? Patient Educ Couns. 2002;46(1):1-9.

7. Santos FLMM, Araújo TL. Vivendo infarto: os significados da doença segundo a perspectiva do paciente. Rev. Latino-Am. Enfermagem. 2003;11(6):742-8.

8. Moser DK, McKinley S, Dracup K, Chung ML. Gender differences in reasons patients delay in seeking treatment for acute myocardial infarction symptoms. Patient Educ Couns. 2005;56(1):45-54.

9. Antman EM, Hand M, Armstrong W, Bates ER, Green LA, Halasyamani LK, et al. 2007 Focused update of the ACC/AHA 2004 guidelines for the management of patients with st-elevation myocardial infarction. Circulation. 2008;117(2):1-34.

10. Masoudi FA, Bonow RO, Brindis RG, Cannon CP, DeBuhr J, Fitzgerald S, et al. ACC/AHA 2008 Statement on performance measurement and reperfusion therapy. J Am Coll Cardiol. 2008;52(24):2100-12.

11. Henriksson C, Lindahl B, Larsson M. Patients' and relatives' thought and actions during and after symptom presentation for an acute myocardial infartion. Eur J Cardiovasc Nurs. 2007;6(4):280-6.

12. MacInnes JD. The illness perceptions of women following symptoms of acute myocardial infartion: A sef-regulatory approach. Eur J Cardiovasc Nurs. 2006;5(4):280-8.

13. Arnetz JE, Arnetz BB. Gender differences in patient perceptions of involvement in myocardial infarction care. Eur J Cardiovasc Nurs. 2008;17(3):393-405.

14. Jneid $\mathrm{H}$, Fonarow GC, Cannon $\mathrm{CP}$, Hernandez AF, Palacios IF, Maree AO, et al. Sex differences in medical care and early death after acute myocardial infarction. Circulation. 2008;118(25):2803-10.

15. Passos LCS, Lopes AA, Esteves FP, Santos FMO. Diferença de letalidade hospitalar do infarto agudo do miocárdio entre homens e mulheres submetidos a angioplastia primária. Arq Bras Cardiol. $1998 ; 71(4): 587-90$.
16. Goldberg RJ, Gabriel P, Sadiq I, Granger CB, Jackson EA, Budaj A, et al. Extent of, and factors associated with, delay to hospital presentation in patients with acute coronary disease (The GRACE registry). Am J Cardiol. 2002;89(7):791-6.

17. Goldberg RJ, Spencer FA, Fox KAA, Brieger D, Steg G, Gurfinkel E, et al. Prehospital delay in patients with acute coronary syndromes - from the global registry of acute coronary events [GRACE]. Am J Cardiol. 2009;103(5):598-603.

18. Perkins-Porras L, Whitehead DL, Strike PC, Steptoe A. Pre-hospital delay in patients with acute coronary syndrome: factors associeated with patient decision time and home-to-hospital delay. Eur J Cardiovasc Nurs. 2009;8(1):26-33.

19. Buckley T, McKinley S, Gallagher R, Dracup K, Moser DK, Aitken LM. The effect of education and counselling on knowledge, attitudes and beliefs about responses to acute myocardial infarction symptoms. Eur J Cardiovasc Nurs. 2007;6(2):105-11.

20. Fukuoka Y, Dracup Kathleen, Kobayashi F, Froelicher ES, Rankin SH, Ohno M, et al. Trajectory of prehospital delay in patients with acute myocardial infarction in the Japanese health care system. Int J Cardiol. 2006;107(2):188-93.

21. Pinto DS, Kirtane AJ, Nallamothu BK, Murphy SA Cohen DJ, Laham RJ, et al. Hospital delays in reperfusion for ST-elevation myocardial infarction. Circulation. 2006;114(19):2019-25.

22. Mcginn AP, Rosamond WD, Goff DC, Taylor HA, Miles JS, Chambless $L$, et al. Trends in prehospital delay time and use of emergency medical services for acute myocardial infarction: experience in 4 US communities from 1987-2000. Am Heart J. 2005;150(3):392-400.

23. Mussi FC. O infarto e a ruptura com o cotidiano: possível atuação da enfermagem na prevenção. Rev. Latino-Am. Enfermagem. 2004;12(5):751-9.
Received: July 24 2010 Accepted: June $14^{\text {th }} 2011$ 